\title{
KEMAMPUAN BERKOMITMEN PARA PELAKU UMKM DALAM PENGEMBALIAN MODAL PINJAMAN/KREDIT SEBAGAI LANDASAN PRINSIP KEPERCAYAAN (Kondisi UMKM di Kecamatan Bogor Selatan)
}

\section{Oleh}

\section{Jaenudin, Lia Dahlia Iryani, Tiara Timuriana, dan Dessy Herlisnawati}

\begin{abstract}
Abstrak
Para pengusaha yang dapat bertahan pada masa krisis ekonomi, kebanyakan berasal dari usaha yang berskala kecil dan menengah, dikarenakan sebagian besar tidak berhubungan dengan perbankan yang pada saat itu tengah dilanda krisis. Namun seiring membaiknya kondisi perekonomian, para pelaku UMKM perlu memiliki akses perbankan terutama untuk meningkatkan produktivitas dan kemampuan berwirausahanya.

Penelitian ini dimaksudkan untuk menggali potensi para pelaku UMKM di wilayah Kecamatan Bogor Selatan, khususnya yang menyangkut komitmen dengan pihak pemberi kredit agar memperoleh kemudahan dalam bantuan kredit dari perbankan. Penelitian ini membatasi permasalahan pada: berapa dan darimana modal awal para pelaku UMKM; bagaimana pengelolaan modal pinjaman yang dilakukan para pelaku UMKM; dan bagaimana kemampuan para pelaku UMKM berkomitmen untuk memenuhi syarat kredit dari perbankan.

Berdasarkan hasil penelitian, bahwasanya jenis modal pada saat pendirian dominan diperoleh melalui modal sendiri sebanyak $86,25 \%$, sedangkan yang menggunakan fasilitas modal pinjaman hanya $4,375 \%$ dari para pelaku UMKM. Adapula UMKM yang menggunakan modal campuran yaitu modal sendiri ditambah dengan modal pinjaman sebanyak 8,75\%; dan terlihat hanya $8 \%$ pelaku UMKM yang terlibat dengan pihak bank, sedangkan 92\% lainnya belum pernah melakukan peminjaman dengan pihak bank; Sedangkan untuk besarnya pencapaian laba operasional sebanyak 79\% para pelaku UMKM mendapatkan
\end{abstract}


keuntungan pada kisaran Rp1.000.000 sampai dengan Rp10.000.000. Hal tersebut merupakan cerminan kemampuan para pelaku UMKM untuk dapat memiliki akses perbankan. Dimana kemampuannya dalam mengembalikan pinjaman dapat dilakukan sesuai dengan kesepakatan yang telah ditetapkan.

Kata Kunci : Modal Awal, Modal Sendiri, Modal Pinjaman serta Laba Operasional.

\section{PENDAHULUAN}

\subsection{Latar Belakang Penelitian}

UMKM menjadi pusat perhatian karena tingkat perekonomian dan pengetahuan yang "kurang maju" dalam bisnis. UMKM menghadapi kendala-kendala dalam mempertahankan atau mengembangkan usaha (bisnis), antara lain kurang pengetahuan pengelolaan usaha, kurang modal dan lemah dibidang pemasaran. Untuk mengatasinya UMKM harus merencanakan strategi bisnis yang tepat.

Memperhatikan sedikitnya Usaha Kecil dan Menengah yang memiliki akses ke dalam dunia perbankan disebabkan banyak faktor, antara lain adanya keterbatasan kewenangan dari pihak perbankan dan keterbatasan dari pihak UMKM seperti perizinan usaha, agunan tambahan seperti status tanah yang bermasalah, pengelolaan manajemen usaha, tidak adanya laporan keuangan, serta akses pasar yang terbatas. Kendala utama yang dihadapi para pengusaha yang berskala kecil dan menengah untuk memasuki dunia perbankan adalah masalah pengelolaan manajemen keuangan.

Berdasarkan perumusan masalah diatas maka tujuan pelaksanaan penelitian ini adalah untuk menggali potensi para pelaku UMKM diwilayah kecamatan Bogor Selatan, khususnya yang menyangkut komitmen dengan pihak pemberi kredit agar memperoleh kemudahan dalam bantuan kredit dari perbankan. Penelitian ini membatasi permasalahan pada: berapa dan darimana modal awal para pelaku UMKM; bagaimana pengelolaan modal pinjaman yang dilakukan para pelaku 
UMKM; dan bagaimana kemampuan para pelaku UMKM berkomitmen untuk memenuhi syarat kredit dari perbankan.

Manfaat pelaksanaan penelitian ini adalah memberikan gambaran mengenai kemampuan para pelaku UMKM di wilayah kecamatan Bogor Selatan, khususnya dalam komitmen syaratsyarat kredit dari perbankan. Sehingga dunia perbankan mendapatkan sedikit tambahan informasi yang dapat dijadikan sebagai landasan dalam kebijakan memberikan modal pinjaman/kredit kepada UMKM di wilayah kecamatan Bogor Selatan.

\subsection{Identifikasi Masalah}

Identifikasi masalah yang diangkat dalam penelitian ini adalah:

1. Berapa modal awal para pengusaha UMKM?

2. Bagaimana pengelolaan modal pinjaman yang dilakukan para pengusaha UMKM?

3. Bagaimana kemampuan para pengusaha UMKM berkomitmen untuk memenuhi syarat kredit dari perbankan?

\subsection{Maksud dan Tujuan Penelitian}

Maksud dari penelitian ini adalah memberikan gambaran mengenai kemampuan para pelaku UMKM di wilayah kecamatan Bogor Selatan, khususnya dalam komitmen syaratsyarat kredit dari perbankan. Sehingga dunia perbankan mendapatkan sedikit tambahan informasi yang dapat dijadikan sebagai landasan dalam kebijakan memberikan modal pinjaman/kredit kepada UMKM di wilayah kecamatan Bogor Selatan. Sesuai dengan judul dan identifikasi masalah tersebut, maka tujuan penelitian ini adalah :

1. Untuk mengetahui gambaran modal awal para pengusaha UMKM.

2. Untuk mengetahui pengelolaan modal pinjaman yang dilakukan para pengusaha UMKM.

3. Untuk mengetahui kemampuan para pengusaha UMKM berkomitmen untuk memenuhi syarat kredit dari perbankan? 


\section{LANDASAN TEORI}

\subsection{Definisi dan Karakteristik UMKM}

Mengacu dalam pasal 6 Undang-Undang No.20 Tahun 2008 tentang UMKM, kriteria usaha mikro adalah sebagai berikut:

1. Memiliki kekayaan bersih paling banyak Rp50.000.000,00 (tidak termasuk tanah dan bangunan tempat usaha); atau

2. Memiliki hasil penjualan tahunan paling banyak Rp300.000.000,00.

Untuk Kriteria usaha kecil:

1. Memiliki kekayaan bersih paling banyak Rp50.000.000,00 sampai dengan paling banyak Rp500.000.000,00. (tidak termasuk tanah dan bangunan tempat usaha); atau

2. Memiliki hasil penjualan tahunan paling banyak Rp300.000.000,00. sampai dengan paling banyak Rp2.500.000.000,00.

Sedangkan Usaha Menengah :

1. Memiliki kekayaan bersih lebih dari Rp500.000.000,00. sampai dengan paling banyak Rp10.000.000.000,00. (tidak termasuk tanah dan bangunan tempat usaha); atau

2. Memiliki hasil penjualan tahunan lebih dari Rp2.500.000.000,00 sampai dengan paling banyak Rp50.000.000.000,00.

Kriteria ini perlu diketahui oleh para pelaku UMKM agar dapat menyesuaikan usahanya dengan criteria sesuai UU No 20 UMKM. Terutama dalam berhubungan pihak lain (lembaga keuangan bank/non bank dan rekan bisnis) termasuk pula untuk penyusunan dokumen legal (surat-surat ijin).

Kriteria diatas sudah jauh berubah apabila dibandingkan dengan criteria sebelumnya. Tentunya semua dilakukan untuk kemajuan usaha para pelaku usaha UMKM.

Sedangkan karakteristik umum UMKM menurut Napa J Liwa dan Muljadi, dilihat dari ciri-cirinya pada dasarnya biasa dianggap sama, yaitu sebagai berikut:

1. Struktur organisasi yang sangat sederhana.

2. Tanpa Staf yang berlebihan.

3. Pembagian kerja yang "kendur".

4. Memiliki hirarki manajerial yang pendek. 
5. Aktivitas sedikit yang formal, dan sedikit menggunakan proses perencanaan.

6. Kurang membedakan asset pribadi dari asset perusahaan.

UMKM menjadi pusat perhatian karena tingkat perekonomian dan pengetahuan yang "kurang maju" dalam bisnis. UMKM menghadapi kendala-kendala dalam mempertahankan atau mengembangkan usaha (bisnis), antara lain kurang pengetahuan pengelolaan usaha, kurang modal, dan lemah dibidang pemasaran. Kondisi pasar yang dihadapi UMKM adalah persaingan monopolistik, disamping itu merupakan fakta yang perlu diperhatikan. Untuk mengatasinya UMKM harus merencanakan strategi bisnis yang tepat.

\subsection{Permodalan Usaha Kecil Menengah}

Pada dasarnya semua usaha dapat dimodali dengan modal sendiri maupun modal asing/pinjaman. Namun pada umumnya permodalan UMKM masih didasrkan pada kemampuan keuangan pribadi, tentunya hal ini mengakibatkan permodalan UMKM masih lemah

Mengingat UMKM memberi kontribusi yang tidak sedikit, sehingga pemerintah berupaya untuk membantu UMKM dalam menyediakan sumber dana tambahan untuk mengembangkan usahanya.

Titik Sartika \& Abd. Rachman Soejoedono, berpendapat bahwa arah kebijakan pengembanan yang khusus memfokuskan pada penyediaan modal perlu menentukan strategi sebagai berikut:

1. Memadukan dan memperkuat tiga aspek yaitu bantuan keuangan, bantuan teknis, dan program peminjaman.

2. Mengoptimalkan penunjukkan bank dan lembaga keuangan mikro untuk usaha mikro kecil-menengah (UMKM).

3. Mengoptimalkan realisasi business plan perbankan dalam pemberian KUK (Kredit Usaha Kecil).

4. Bantuan teknis yang efektif, bekerja sama dengan asosiasi, konsultan swasta, perguruan tinggi, dan lembaga terkait.

5. Meningkatkan lembaga penjamin kredit yang ada, dan 
6. Memperkuat lembaga keuangan mikro untuk melayani masyarakat miskin.

Berdasarkan Undang-undang No. 23 tahun 1999 tentang Bank Indonesia, kegiatan yang masih dilakukan oleh Bank Indonesia dalam membantu pengembangan usaha kecil adalah sebagai berikut:

1. Ketentuan Kredit Usaha Kecil (KUK), melalui Peraturan Bank Indonesia Nomor: 3/2/PBI/2001 tentang Pemberian Kredit Usaha Kecil ditetapkan bahwa: (i) Bank dianjurkan menyalurkan dananya melalui pemberian KUK, (ii) Bank yang melaksanakan pemberian KUK wajib mencantumkan rencana pemberian KUK dalam rencana kerja anggaran tahunan (RAKT) bank, (iii) Bank yang melaksanakan pemberian KUK wajib melaporkan pelaksanaan pemberian KUK dalam laporan bulanan bank umum, (iv) bank yang melaksanakan pembaerian KUK wajib mengumumkan pencapaian pemberian KUK kepada masyarakat melalui laporan keuangan publikasi, (v) plafon KUK disesuaikan menjadi Rp500.000,00 per nasabah, (vi) Bank yang menyalurkan KUK dapat meminta antuan teknis dari Bank Indonesia, dan (vii) pengenaan sanksi dan insentif dalam rangka pencapaian kewajiban KUK dihapuskan. (www.bi.go.id).

2. Melanjutkan bantuan teknis, Bank Indonesia tetap akan membantu pengembangan usaha kecil secara tidak langsung dengan meningkatkan intensitas dan efektivitas bantuan teknis untuk pengembangan usaha kecil dan mikro (PUMKM) melalui:

a. Perluasan akses ke sumber informasi berupa (i). Sistem Informasi Baseline Economic Survey (SIB), yaitu sistem yang mengajukan daftar komoditi di kecamatan pada 22 propinsi yang potensial untuk dikembangkan, dan (ii) Sistem Informasi Agro Industri Berorientasi Ekspor (SIABE), yaitu sistem yang menyajikan informasi mengenai komoditi agro industri yang berpotensi untuk diekspor.

b. Menyediakan informasi mengenai komoditi yang layak dibiayai oleh bank atau dikenal dengan lending model. 
3. Melanjutkan Proyek Kredit Mikro bank Indonesia (Linkage program). Proyek Kredit Mikro (PKM), adalah proyek pemerintah yang dibantu dengan dana penjamin Asian Development Bank (ADB) yang dimulai sejak tahun 1995. PKM dilakukan dengan cara Bank Indonesia ditunjuk sebagai executing agency. Bank Indonesia untuk sementara tetap berperan sebagai executing agent sampai dengan proyek ini dapat dialihkan ke lembaga yang ditunjuk pemerintah. Mekanisme untuk mendapatkan PKM adalah dengan cara nasabah baru pengusaha mikro yang belum pernah mendapatkan fasilitas pinjaman dari BPR partisipan PKM, baik individu maupun dalam kelompok. Permohonan pinjaman PKM diajukan nasabah baru kepada BPR seperti peserta PKM sebagaimana mekanisme pinjaman umum yang berlaku di BPR tersebut, dengan maksimum pinjaman ulangan Rp5.000.000,00. dana pinjaman ADB disalurkan di 15 propinsi melaui BPR yang memenuhi criteria PKM sebagai berikut:

a. Tingkat kesehatan (TKS) 3 bulan terakhir minimal cukup sehat (CS).

b. Capital adequency ratio (CAR) minimal 8\%.

c. Kualitas aktiva produktif (KAP) minimal CS.

d. Manajemen minimal CS.

e. Porsi nasabah mikro minimal 5\% dari total nasabah, dan

f. Porsi tabungan terhadap pinjaman minimal $10 \%$.

\section{HIPOTESIS PENELITIAN}

Berdasarkan pemahaman teoretis bahwa arah kebijakan pengembangan UMKM yang khusus memfokuskan pada penyediaan modal perlu menentukan strategi dalam memadukan dan memperkuat tiga aspek yaitu bantuan keuangan, bantuan teknis, dan program peminjaman.

Memperhatikan banyaknya jumlah pengusaha UMKM yang tersebar di wilayah Kecamatan Bogor Selatan dimana terdapat 160 UMKM yang merupakan responden penelitian 
ini, maka dapat dikatakan bahwa keberadaan UMKM memiliki potensi besar dalam meningkatkan pengembangan perekonomian khususnya diwilayah Kecamatan Bogor Selatan.

Guna memperoleh kondisi seperti tersebut, maka pemerintah daerah khususnya perlu memberikan respon positif terhadap pengembangan UMKM ditilik dari bantuan keuangan, dengan syarat yang dipermudah sehingga dapat meningkatkan perekonomian daerah setempat.

Oleh karena itu, berdasarkan identifikasi masalah dan pemahaman teoretis, maka hipotesis penulis dalam penelitian ini adalah bahwa keberaadaan UMKM dalam komitmen berkomitmen untuk memenuhi syarat kredit dari perbankan dapat didukung oleh pemerintahan setempat dalam hal bantuan keuangan guna tercapainya peningkatan perekonomian.

\section{METODE PENELITIAN}

Metode riset merupakan rencana tentang cara mengumpulkan dan menganalisis data agar dapat dilaksanakan secara ekonomis serta serasi dengan jenis dan tujuan penelitian.

Metode riset terdiri dari :

- Jenis, Metode dan Teknik Penelitian

a) Jenis Penelitian

Jenis penelitian yang digunakan peneliti adalah Deskriptif eksploratif yaitu yang bertujuan untuk menggali informasi sehingga diperoleh gambaran dan uraian tentang kemampuan UMKM dalam pengembalian modal pinjamannya.

b) Metode Penelitian

Metode yang digunakan adalah studi kasus yaitu proses pengumpulan data yang dilakukan dengan jalan mencermati kasus mengenai kemampuan UMKM dalam pengembalian modal pinjamannya.

c) Teknik Penelitian 
Penulis menggunakan teknik penelitian Statistik Kualitatif yaitu penelitian statistic yang mencari jawaban secara mendasar tentang semua hal yang berkaitan erat dengan kemampuan UMKM dalam pengembalian modal pinjamannya.

d) Analisis data

Metode analisis data dalam penelitian ini adalah deskriptif kualitatif yaitu menjelaskan gambaran perumusan masalah yang dijabarkan indikator-indikator penelitiannya sebagai berikut:

1. Profil responden UMKM di wilayah Kecamatan Bogor Selatan ( Jenis usaha UMKM dan lama usahanya);

2. Permodalan UMKM di wilayah Kecamatan Bogor Selatan (Sumber modal, Modal awal, besarnya modal pinjaman);

3. Pengelolaan modal pinjaman UMKM di wilayah Kecamatan Bogor Selatan (Jumlah UMKM yang melakukan peminjaman ke Bank, Lokasi Bank tempat meminjam, Jumlah pinjaman ke Bank, Jangka waktu pengembalian dan pelunasan);

4. Pencapaian laba operasional UMKM, sebagai indikator kemampuan UMKM berkomitmen untuk memenuhi syarat kredit dari perbankan.

\section{HASIL PENELITIAN}

Berdasarkan resume hasil penelitian, informasi yang diperoleh dan dijadikan sebagai landasan dalam kebijakan memberikan modal pinjaman/kredit kepada UMKM di wilayah kecamatan Bogor Selatan, sebagai berikut :

1. Profil responden UMKM di wilayah Kecamatan Bogor Selatan (Jenis usaha UMKM dan lama usahanya).

a. Para pelaku UMKM yang memiliki jenis usaha terbesar diwilayah kecamatan Bogor Selatan bergerak dalam usaha dagang berupa toko atau warung kelontong sebanyak 47\%. Kemudian sebanyak $27 \%$ diminati untuk usaha jasa dan selebihnya bergerak pada usaha produksi barang $12 \%$, rumah makan $12 \%$. 
b. Sedikitnya UMKM yang dilihat dari lama usahanya, maka sebanyak 63\% responden UMKM menjalankan usahanya selama kurun waktu 1 sampai dengan 10 tahun. Berikutnya untuk selang waktu $<1$ tahun terdapat $11 \%$ UMKM dan salang waktu 11 sampai dengan 20 tahun tedapat 14\% UMKM, selebihnya rentang usaha untuk >20 tahun, hanya diminati 5\% para pelaku UMKM.

2. Permodalan UMKM di wilayah Kecamatan Bogor Selatan (Sumber modal, Modal awal, besarnya modal pinjaman).

a. Bahwasanya jenis modal pada saat pendirian dominant diperoleh melalui modal sendiri sebanyak $86,25 \%$, sedangkan yang menggunakan fasilitas modal pinjaman hanya 4,375\% responden dari para pelaku UMKM. Adapula UMKM yang menggunakan modal campuran yaitu modal sendiri ditambah dengan modal pinjaman sebanyak 8,75\%.

b. Untuk besarnya modal awal UMKM, kisaran modal terbesar berada pada rentang Rp.1.000.001Rp10.000.000, sebesar 46\% dan < Rp1.000.000, sebesar 31\%. Selebihnya untuk rentang Rp10.000.001-Rp.20 juta sebesar 13,125\% dan hanya sekitar 3\% yang memiliki modal lebih dari lima puluh juta.

c. Sedangkan besarnya modal pinjaman para pelaku UMKM terbesar 53\% ada pada rentang Rp1.000.001Rp10.000.000, untuk Rp10.000.001-Rp.20.000.000 sebesar 19\%, serta < Rp1.000.000 sebesar 14\% dan ada juga modal pinjaman paa kisaran $>$ Rp50.000.000 yaitu sebesar $14 \%$. Modal pinjaman para pelaku UMKM sebagian besar masih terkait dengan ikatan kekerabatan dan sedikit sekali yang menggunakan jasa dari pihak bank maupun pemerintah.

3. Pengelolaan modal pinjaman UMKM di wilayah Kecamatan Bogor Selatan (Jumlah UMKM yang melakukan peminjaman ke Bank, Lokasi Bank tempat meminjam, Jumlah pinjaman ke Bank, Jangka waktu pengembalian dan pelunasan). 
a. UMKM diwilayah kecamatan Bogor Selatan hanya sekitar 4\% yang memulai usahanya dengan modal pinjaman. Untuk pelaku UMKM yang melakukan peminjaman ke bank hanya 8\%, sedangkan 92\% lainnya belum pernah melakukan peminjaman dengan pihak bank.

b. Lokasi bank tempat meminjam para pelaku UMKM yang memiliki prioritas utama yaitu bank BRI, bank BPR dan Bank Mandiri sebesar 17\%. Selanjutnya sebesar 8\% tujuan para pelaku UMKM ke pihak bank BNI dan bank Jabar, juga terdapat 33\% responden yang tidak menjawab, yang disebabkan pilihan tempat meminjam lebih kepada sanak saudara atau pihak renternir.

c. Untuk mengetahui besarnya pinjaman kepada pihak bank, sebanyak 34\% responden melakukan peminjaman dalam rentang Rp1.000.001Rp5.000.000. Selanjutnya ada sebesar 25\% responden melakukan peminjaman dalam rentang Rp5.000.000Rp10.000.000. Berikutnya pinjaman > Rp20.000.000 sebesar $17 \%$ responden menjawab. Selebihnya $8 \%$ responden melakukan peminjaman dalam rentang < Rp1.000.000, Rp.10.000.000-Rp.15.000.000 dan Rp15.000.001-Rp.20.000.000.

d. Untuk jangka waktu peminjaman pada pihak bank, sebanyak 51\% responden melakukan jangka waktu pinjaman selama 2 tahun. Selanjutnya ada sebesar 33\% dalam jangka waktu 1 tahun. Selebihnya sebesar $8 \%$ dalam jangka waktu masing-masing < dari 1 tahun dan 3 tahun.

e. Selanjutnya untuk melihat kemampuan para pelaku UMKM dalam mengembalikan pinjaman, terbesar ada pada rentang 1-5 tahun yaitu sebesar $47 \%$ dan $43 \%$ untuk jangka waktu pelunasan < dari satu tahun. Hanya 5\% responden yang menjawab jangka waktu pelunasan $>$ dari 5 tahun. 
4. Pencapaian laba operasional UMKM, sebagai indikator kemampuan UMKM berkomitmen untuk memenuhi syarat kredit dari perbankan.

a. Pencapaian laba operasional ini diperoleh dari nilai pendapatan per bulan dari responden kemudian dikurangi engan beban-beban, antara lain: beban sewa, beban penerangan, beban pembantu, beban bahan baku, beban penyusutan bangunan tempat usaha dan beban penyusutan mesin usaha.

b. Besarnya pencapaian laba operasional bagi para pelaku UMKM diwilayah kecamatan Bogor Selatan ada pada kisaran Rp1.000.001-Rp10.000.000, yaitu sebesar 79\%. Untuk laba operasional pada kisaran < dari Rp1.000.000 adalah sebesar 27\% dan Rp10.000.001Rp20.000.000 sebesar 15\%.

c. Secara keseluruhan dapat disimpulkan bahwa para pelaku UMKM di wilayah kecamatan Bogor Selatan memiliki kemampuan dalam pengelolaan keuangannya, hal ini dapat terlihat berdasarkan pencapaian laba opeasional sebanyak $79 \%$ responden mendapatkan keuntungan pada kisaran Rp1.000.001 sampai dengan Rp10.000.000. Sehingga para pelaku tersebut dapat mengembalikan pinjaman sesuai dengan kesepakatan yang telah ditetapkan.

\section{PENUTUP}

Dimana pada akhirnya para pelaku UMKM haruslah mendapat perhatian serius dari pemerintah pusat maupun daerah. Serta haruslah mendapat pembinaan untuk peningkatan kualitas dari usaha yang digelutinya, karena pelaku UMKM sudah terbukti mampu menghidupi puluhan bahkan ratusan juta jiwa.. Misalnya para pedagang asongan maupun loper koran sudah terbukti memiliki jiwa enterpreneur sejati. Karena meski harus berdagang dalam keterbatasan modal, namun masih bisa bertahan. Pelaku UMKM yang seperti itulah yang harus mendapat bantuan dan binaan untuk pengembangan usahanya. 
Namun diharapkan bantuan permodalan yang diberikan haruslah tanpa menggunakan agunan/jaminan.

Untuk kajian riset lebih lanjut perlu untuk mengetahui studi bagi kepentingan pelaku UMKM dalam bantuan dan binaan untuk pengembangan usahanya, sehingga bisa menjadi bahan masukan dan perhatian serius dari pemerintah daerah Bogor, khususnya di kecamatan Bogor Selatan.

\section{DAFTAR PUSTAKA}

\section{Buku}

Kasmir. 2002. Dasar-dasar Perbankan. Edisi 1, PT. Raja Grafindo Persada, Jakarta.

Peraturan Menteri Negara Koperasi dan UMKM. Nomor.02/PER/M.KUMKM/I/2008. Tentang Usaha Kecil dan Menengah. Jakarta.

Sugiyono. 2003. Metode Penelitian Bisnis. Alfa Beta. Bandung. Undang-Undang No. 10 Tahun 1998 tentang Perbankan.

Undang-Undang No.20, Pasal 6, Tahun 2008. Tentang Usaha Mikro, Kecil dan Menengah. Jakarta.

Van Horne C, James and Wachowicz M, John. 2005. "Fundamental of Financial Management", Penerjemah: Dewi Fitriasari dan Deny Arnos Kwary. Buku satu. Edisi 12. Penerbit Salemba Empat. Jakarta.

F. Brigham, Eugene and F. Houston, Joel. 2006. "Fundamental of Financial Management". Penerjemeh: Ali Akbar Yulianto. Buku satu. Edisi 10. Penerbit Salemba Empat. Jakarta.

\section{Homepage}

.,http "www.bi.co.id, Bank Indonesia.

Bisnis Indonesia. 2005. Isu lama bayangi langkah Kemenkop \& UMKM. http:///www. Bisnis.Com ( Diakses Februari 2005 ).

Deddy Edward Tanjung.2009. Usaha Mikro, Kecil dan Menengah. http://usaha-umkm blog.com (Diakses 2009).

Menteri Negara Koperasi dan Usaha Kecil Menengah. 2004. Daerah Diberi Porsi Besar Bangun KUMKM. 
http://www.Media Indonesia Online.Com ( Diakses Februari 2005 )

Menkop dan UMKM. Suryadharma Ali. 2004. Kredit Macet UMKM Capai Rp.8.8 Triliun. http://www.Media Indonesia Online.Com ( Diakses Februari 2005).

Presiden Megawati Soekarnoputri. 2004. Presiden Akui Peran UMKM sangat Besar. http://www. Media Indonesia Online.Com 


\section{Lampiran}

\section{RESUME DATA PENELITIAN}

\section{PROFIL RESPONDEN}

\section{Jenis Usaha}

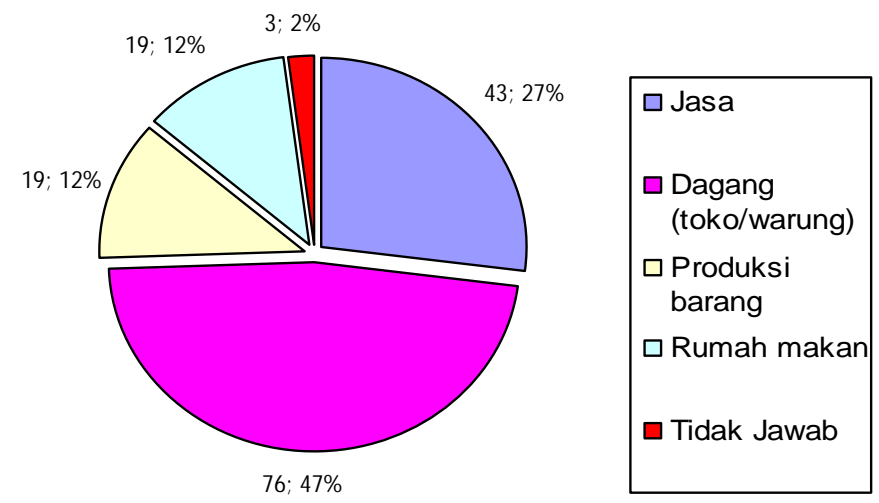

\section{Lama Usaha}

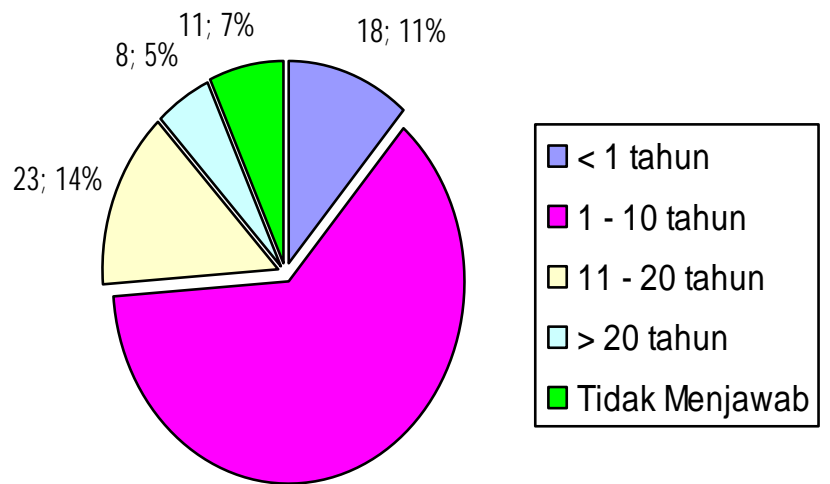

$100 ; 63 \%$

Jurnal Ilmiah Manajemen dan Akuntansi Fakultas Ekonomi (JIMAFE) 


\section{KONDISI KEUANGAN}

\section{Besarnya Modal Awal}
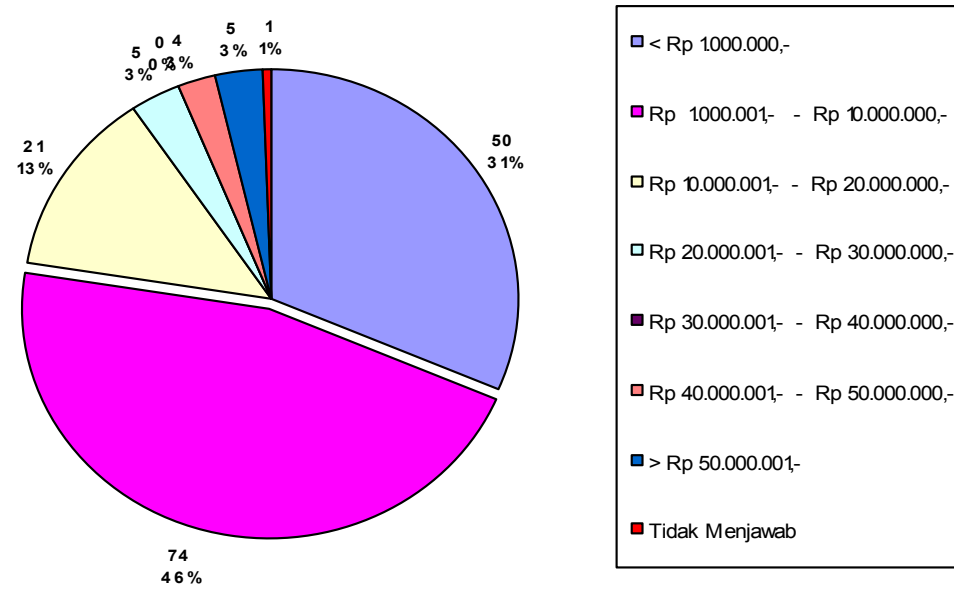

\section{Jenis Modal pada Saat Pendirian}

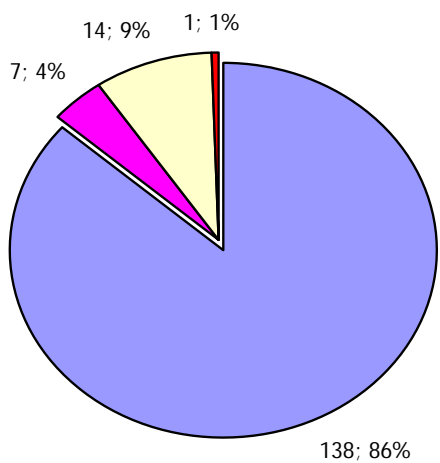

$$
\begin{aligned}
& \square \text { Modal Sendiri } \\
& \square \text { Modal Pinjaman } \\
& \square \text { Campuran (Sendiri + } \\
& \text { Pinjaman) } \\
& \square \text { Tidak Menjawab }
\end{aligned}
$$

$138 ; 86 \%$ 


\section{Besarnya Modal Pinjaman}

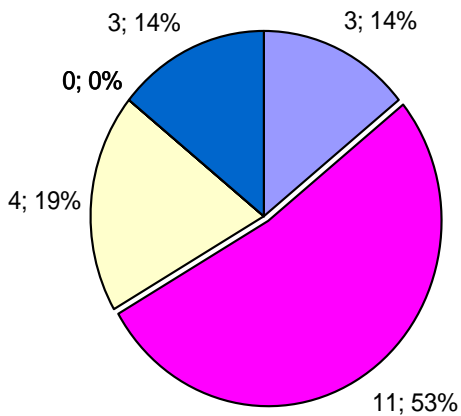

$\square<\operatorname{Rp} 1.000 .000,-$

口 Rp 1.000.001,- - Rp 10.000.000,-

口Rp 10.000.001,- - Rp 20.000.000,-

口Rp 20.000.001,- - Rp 30.000.000,-

- Rp 30.000.001,- - Rp 40.000.000,-

口Rp 40.000.001,- - Rp 50.000.000,-

口 > Rp 50.000.001,-

\section{Peminjaman ke Bank}

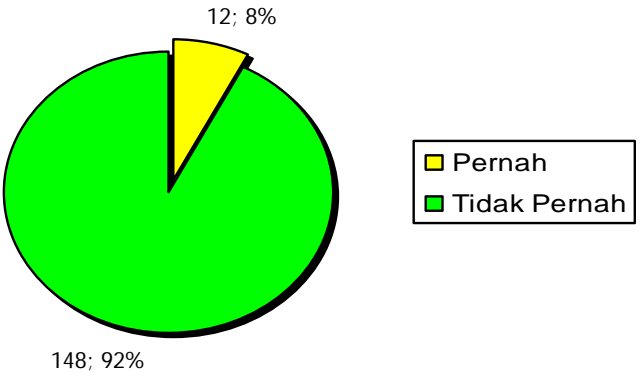

\section{Jumlah Pinjaman ke Bank}

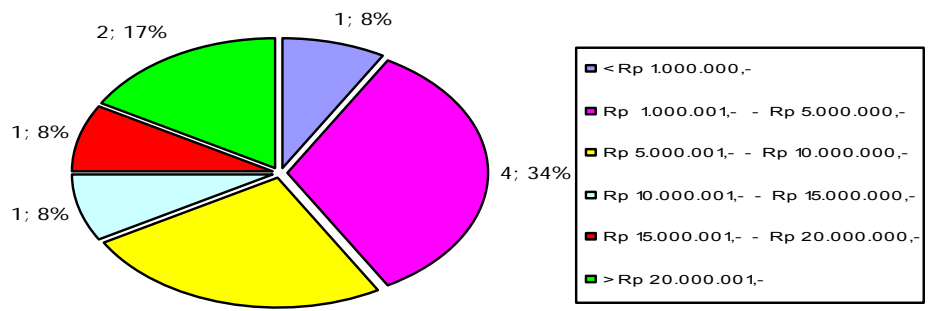

3; $25 \%$ 


\section{Jangka Waktu Peminjaman ke Bank}

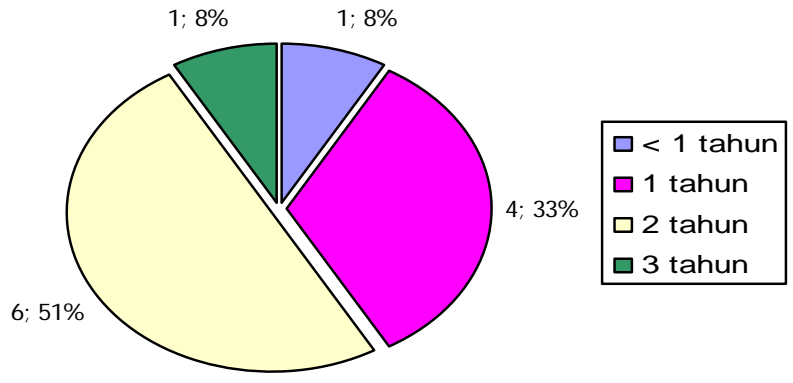

\section{Jangka Waktu Pelunasan}

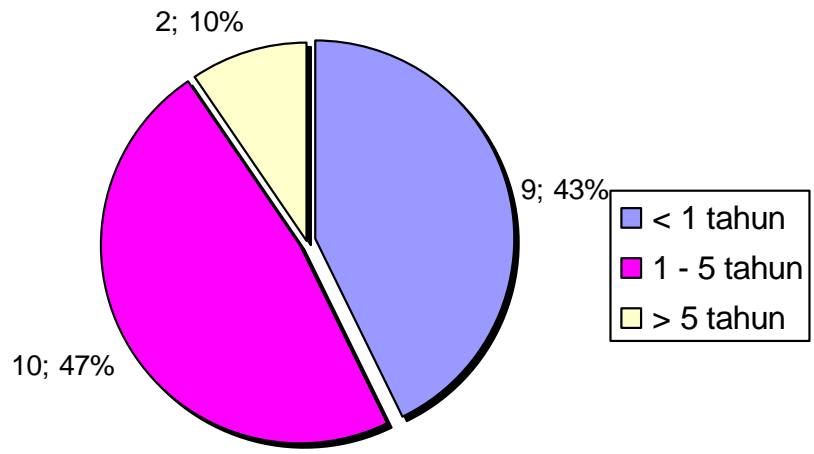




\section{Pelunasan Modal Pinjaman}

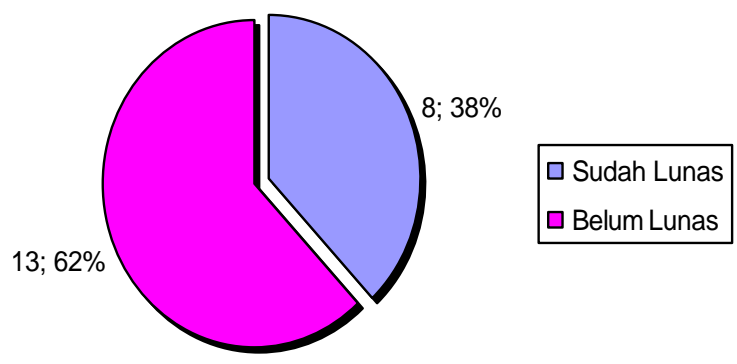

\section{Pencapaian Laba Operasional}

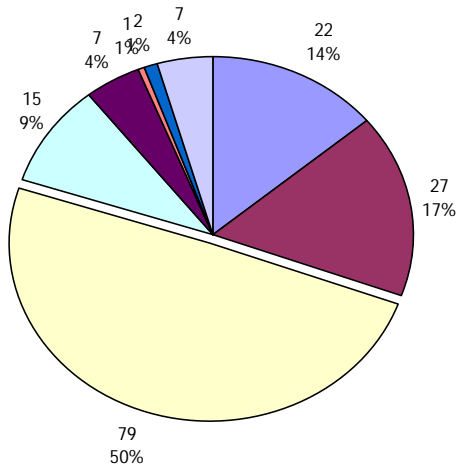

$\square<0$

$\square<1,000,000$

口 1,000,001-10,000,000

ㄴ,000,001-20,000,000

口20,000,001-30,000,000

궁, $000,001-40,000,000$

$\square$ 40,000,001-50,000,000

$\square>50,000,000$ 
